\author{
V.M. Yurov, G.A. Ranova, S.A. Guchenko, V.Ch. Laurinas \\ Ye.A. Buketov Karaganda State University, Kazakhstan \\ (E-mail: exciton@list.ru)
}

\title{
To the question of the thermal conductivity of metallic nanothreads and nanofilms
}

\begin{abstract}
In recent years, attention has been growing in the study of the thermophysical properties of nanostructures, which is due to the opportunities that open with the use of these structures in virtually all fields of science, technology, medicine, etc. Studies show that there are significant differences in the nature of heat transfer within macroscopic bodies and in nanostructures. Another feature of this problem is the large variety of objects that require the development of special theoretical and experimental research methods. In this connection, the issues of heat transfer in solid-state nanostructures are currently an area of active research. As shown by us in a number of papers, the equations (1)-(3) obtained have a universal character and are valid for the dimensional dependence of many properties of nanostructures, including thermophysical ones. In the present paper, this approach is used in considering the thermal conductivity and electrical conductivity of metallic nanostructures and some typical problems of thermal conductivity of thin films. It follows from the results presented in the paper that for metal nanostructures the Fuchs-Sondheimer model works well when taking into account the dimensional dependence of the mean free path of an electron. In all the guidelines for calculating the thermal fields of thin coatings of space and aviation equipment, we start with the classical heat conduction equations, where the thermal conductivity coefficient is assumed to be a constant value. In this paper, we showed that when the thickness of a metal film is less than 50-100 nm, its physical properties are affected by dimensional effects. The problem of the thermal field of an unlimited plate of small thickness is considered. It is shown that the heat field of a nanoplate depends both on the material of the plate through the coefficient of thermal conductivity of a massive sample, and on the size factor. In the classical case, there is no such dependence.
\end{abstract}

Keywords: thermal conductivity, electrical conductivity, nanowire, nanofilms, size effect, thermal physics.

\section{Introduction}

In recent years, attention has been growing in the study of the thermophysical properties of nanostructures, which is due to the opportunities that open with the use of these structures in virtually all fields of science, technology, medicine, etc.

Studies show that there are significant differences in the nature of heat transfer within macroscopic bodies and in nanostructures. Another feature of this problem is the large variety of objects that require the development of special theoretical and experimental research methods. In connection with this, the problems of heat transfer in solid-state nanostructures are currently an area of active research [1-6].

The relation $\ell_{\infty} / L$ determines the character of heat transfer in solids of small dimensions. Here $\ell_{\infty}$ is the mean free path of phonons in a macroscopic sample whose size $L$ is much larger than $\ell_{\infty}$. When it comes to nanostructures, the corresponding characteristic dimensions are considered as $L$. When the inequality $\ell_{\infty} / L<10^{-3}$ is satisfied for all three measurements (for macroscopic bodies), classical diffusion heat transfer is realized, the mechanism of which is determined by the Fourier law. Another limiting value of the ratio $\ell_{\infty} L$ is of the order of $10^{2}$ and corresponds to the so-called Casimir limit $\ell_{\infty} / L>>1$, when practically all phonons transfer heat between the boundaries of bodies without collisions inside a solid. This mechanism of heat transfer is called ballistic. Between these limiting cases, the diffusion-ballistic regime is realized with a change in $\ell_{\infty} / L$ approximately in the range from $10^{-2}$ to 10 . In the indicated range of variation $\ell_{\infty} / L$ there arises an unknown phenomenon in the framework of the classical theory - the dependence of the thermal conductivity on the sample size. In this connection, the so-called effective thermal conductivity $\lambda_{\text {eff }}(L)$ is introduced. This phenomenon can not be explained in the framework of the phenomenological theory of diffusion transport based on the Fourier law. Here we need a statistical theory of the thermal conductivity of solids, laid down by the work of Peierls and Clemens [7, 8].

The above reasoning refers to phonon thermal conductivity, which is realized in dielectrics and semiconductors. For metals, where the transfer of heat is carried out by electrons, the situation is noticeably different. However, in this case the relation $\ell_{\infty} / L$ plays an important role. The thermal conductivity of metallic nanostructures has been much less studied $[9,10]$. In this paper we will analyze the thermal conductivity of nanothreads and nanofilms. 
Dimensional effects in the thermal conductivity of metallic nanostructures

In $[11,12]$ and a number of others we obtained a formula that describes the dependence of the physical property of a solid on its size $r$ :

$$
A(r)=A_{0} \cdot\left(1-\frac{d}{r}\right)
$$

Here $A_{0}$ is the physical property of a massive sample; $A(r)$ is the physical property of a thin film; $d$ is a dimensional parameter. For the size parameter we obtained the formula [11, 12]:

$$
d=\frac{2 \sigma 0}{R T} \text {. }
$$

Here $\sigma$ is the surface tension of a massive sample; $v$ is the molar volume; $R$ is the gas constant; $T$ is the temperature.

For $r<d$, the formula (1) loses its physical meaning $(A(r) \rightarrow \infty)$, so we extend the function $A(r)$ in this region so that the function $A(r)$ vanishes at the point $r=0$. This condition is satisfied when the function (1) is representable in the form:

$$
A(r)=A_{0} \cdot\left(1-\frac{d}{d+r}\right) .
$$

Equations (1)-(3) have a universal character and are valid for the dimensional dependence of many properties of nanostructures, including thermophysical ones. Calculation of the coefficient of thermal conductivity was carried out according to a formula analogous to (3):

$$
\lambda(r)=\lambda_{0} \cdot\left(1-\frac{d}{d+r}\right)
$$

Here $\lambda_{0}$ is the coefficient of thermal conductivity of a massive sample, the value of which is taken from the reference book [13], $d$ is the dimensional parameter, the value of which was obtained by us in [12] and is given in Table 1 . Table 2 gives the value, and in Tables $3-5$ the values of the coefficient of thermal conductivity of nanoparticles of pure metals with sizes 1,10 and $50 \mathrm{~nm}$ are presented.

Table 1

Parameter $d$ of some metals [12]

\begin{tabular}{|c|c|c|c|c|c|c|c|c|c|c|c|c|c|}
\hline $\mathrm{M}$ & $d, \mathrm{~nm}$ & $\mathrm{M}$ & $d, \mathrm{~nm}$ & $\mathrm{M}$ & $d, \mathrm{~nm}$ & $\mathrm{M}$ & $d, \mathrm{~nm}$ & $\mathrm{M}$ & $d, \mathrm{~nm}$ & $\mathrm{M}$ & $d, \mathrm{~nm}$ & $\mathrm{M}$ & $d, \mathrm{~nm}$ \\
\hline $\mathrm{Li}$ & 0.7 & $\mathrm{Sr}$ & 5.8 & $\mathrm{Sn}$ & 1.4 & $\mathrm{Cd}$ & 1.3 & $\mathrm{Fe}$ & 2.2 & $\mathrm{Gd}$ & 5.3 & $\mathrm{Ac}$ & 3.5 \\
\hline $\mathrm{Na}$ & 1.5 & $\mathrm{Ba}$ & 6.2 & $\mathrm{~Pb}$ & 1.8 & $\mathrm{Hg}$ & 0.6 & $\mathrm{Co}$ & 2.0 & $\mathrm{~Tb}$ & 5.3 & $\mathrm{Th}$ & 6.7 \\
\hline $\mathrm{K}$ & 2.6 & $\mathrm{Al}$ & 1.5 & $\mathrm{Se}$ & 1.3 & $\mathrm{Cr}$ & 2.7 & $\mathrm{Ni}$ & 1.9 & $\mathrm{Dy}$ & 5.3 & $\mathrm{U}$ & 2.9 \\
\hline $\mathrm{Rb}$ & 2.9 & $\mathrm{Ga}$ & 0.6 & $\mathrm{Te}$ & 2.5 & $\mathrm{Mo}$ & 4.6 & $\mathrm{Ce}$ & 3.8 & $\mathrm{Ho}$ & 5.5 & $\mathrm{~Np}$ & 1.8 \\
\hline $\mathrm{Cs}$ & 3.6 & $\mathrm{In}$ & 1.1 & $\mathrm{Cu}$ & 1.6 & $\mathrm{~W}$ & 5.8 & $\mathrm{Pr}$ & 4.2 & $\mathrm{Er}$ & 5.5 & $\mathrm{Pu}$ & 1.9 \\
\hline $\mathrm{Be}$ & 1.3 & $\mathrm{Tl}$ & 1.9 & $\mathrm{Ag}$ & 2.2 & $\mathrm{Mn}$ & 2.0 & $\mathrm{Nd}$ & 4.5 & $\mathrm{Tm}$ & 5.2 & $\mathrm{Am}$ & 4.5 \\
\hline $\mathrm{Mg}$ & 2.2 & $\mathrm{Si}$ & 3.4 & $\mathrm{Au}$ & 2.3 & $\mathrm{Tc}$ & 3.6 & $\mathrm{Sm}$ & 4.4 & $\mathrm{Yb}$ & 4.6 & $\mathrm{Bk}$ & 3.6 \\
\hline $\mathrm{Ca}$ & 4.9 & $\mathrm{Ge}$ & 2.8 & $\mathrm{Zn}$ & 1.1 & $\mathrm{Re}$ & 4.6 & $\mathrm{Eu}$ & 5.8 & $\mathrm{Lu}$ & 5.7 & - & - \\
\hline
\end{tabular}

Table 2

Coefficient of thermal conductivity of pure massive metals (M) [13]

\begin{tabular}{|c|c|c|c|c|c|c|c|c|c|c|c|}
\hline $\mathrm{M}$ & $\lambda_{0}, \mathrm{Wt} /(\mathrm{m} \cdot \mathrm{K})$ & $\mathrm{M}$ & $\lambda_{0}, \mathrm{Wt} /(\mathrm{m} \cdot \mathrm{K})$ & $\mathrm{M}$ & $\lambda_{0}, \mathrm{Wt} /(\mathrm{m} \cdot \mathrm{K})$ & $\mathrm{M}$ & $\lambda_{0}, \mathrm{Wt} /(\mathrm{m} \cdot \mathrm{K})$ & $\mathrm{M}$ & $\lambda_{0}, \mathrm{Wt} /(\mathrm{m} \cdot \mathrm{K})$ & $\mathrm{M}$ & $\lambda_{0}, \mathrm{Wt} /(\mathrm{m} \cdot \mathrm{K})$ \\
\hline $\mathrm{Li}$ & 84,8 & $\mathrm{Sr}$ & - & $\mathrm{Sn}$ & 65 & $\mathrm{Cr}$ & 67 & $\mathrm{Ni}$ & 92 & $\mathrm{Ho}$ & 16 \\
\hline $\mathrm{Na}$ & 142,0 & $\mathrm{Ba}$ & - & $\mathrm{Pb}$ & 35 & $\mathrm{Mo}$ & 162 & $\mathrm{Ce}$ & 11 & $\mathrm{Er}$ & 15 \\
\hline $\mathrm{K}$ & 79,0 & $\mathrm{Al}$ & 207 & $\mathrm{Cu}$ & 395 & $\mathrm{~W}$ & 130 & $\mathrm{Pr}$ & 13 & $\mathrm{Tm}$ & 17 \\
\hline $\mathrm{Rb}$ & 58,2 & $\mathrm{Ga}$ & 33 & $\mathrm{Ag}$ & 418 & $\mathrm{Mn}$ & 8 & $\mathrm{Nd}$ & 17 & $\mathrm{Yb}$ & 35 \\
\hline $\mathrm{Cs}$ & 35,9 & $\mathrm{In}$ & 88 & $\mathrm{Au}$ & 310 & $\mathrm{Tc}$ & 51 & $\mathrm{Sm}$ & 13 & $\mathrm{Lu}$ & 16 \\
\hline $\mathrm{Be}$ & 182 & $\mathrm{Tl}$ & 47 & $\mathrm{Zn}$ & 111 & $\mathrm{Re}$ & 50 & $\mathrm{Eu}$ & 14 & & \\
\hline $\mathrm{Mg}$ & 165 & $\mathrm{Si}$ & 167 & $\mathrm{Cd}$ & 93 & $\mathrm{Fe}$ & 75 & $\mathrm{Gd}$ & 11 & & \\
\hline $\mathrm{Ca}$ & 98 & $\mathrm{Ge}$ & 60 & $\mathrm{Hg}$ & 8 & $\mathrm{Co}$ & 71 & $\mathrm{Dy}$ & 11 & & \\
\hline
\end{tabular}


Coefficient of thermal conductivity of metal nanowires with a diameter of $1 \mathbf{~ n m}$

\begin{tabular}{|c|c|c|c|c|c|c|c|c|c|c|c|}
\hline $\mathrm{M}$ & $\begin{array}{c}\lambda(r), \\
\mathrm{Wt} /(\mathrm{m} \cdot \mathrm{K})\end{array}$ & $\mathrm{M}$ & $\begin{array}{c}\lambda(r), \\
\mathrm{Wt} /(\mathrm{m} \cdot \mathrm{K})\end{array}$ & $\mathrm{M}$ & $\begin{array}{c}\lambda(r), \\
\mathrm{Wt} /(\mathrm{m} \cdot \mathrm{K})\end{array}$ & $\mathrm{M}$ & $\begin{array}{c}\lambda(r), \\
\mathrm{Wt} /(\mathrm{m} \cdot \mathrm{K})\end{array}$ & $\mathrm{M}$ & $\begin{array}{c}\lambda(r), \\
\mathrm{Wt} /(\mathrm{m} \cdot \mathrm{K})\end{array}$ & $\begin{array}{c}\lambda(r), \\
\mathrm{Wt} /(\mathrm{m} \cdot \mathrm{K})\end{array}$ \\
\hline $\mathrm{Li}$ & 35.3 & $\mathrm{Sr}$ & - & $\mathrm{Sn}$ & 22 & $\mathrm{Cr}$ & 14 & $\mathrm{Ni}$ & 25 & $\mathrm{Ho}$ & 2 \\
\hline $\mathrm{Na}$ & 45.8 & $\mathrm{Ba}$ & - & $\mathrm{Pb}$ & 10 & $\mathrm{Mo}$ & 22 & $\mathrm{Ce}$ & 2 & $\mathrm{Er}$ & 2 \\
\hline $\mathrm{K}$ & 16.8 & $\mathrm{Al}$ & 65 & $\mathrm{Cu}$ & 120 & $\mathrm{~W}$ & 14 & $\mathrm{Pr}$ & 2 & $\mathrm{Tm}$ & 2 \\
\hline $\mathrm{Rb}$ & 11.2 & $\mathrm{Ga}$ & 17 & $\mathrm{Ag}$ & 102 & $\mathrm{Mn}$ & 2 & $\mathrm{Nd}$ & 2 & $\mathrm{Yb}$ & 5 \\
\hline $\mathrm{Cs}$ & 5.8 & $\mathrm{In}$ & 34 & $\mathrm{Au}$ & 72 & $\mathrm{Tc}$ & 8 & $\mathrm{Sm}$ & 2 & $\mathrm{Lu}$ & 2 \\
\hline $\mathrm{Be}$ & 65 & $\mathrm{Tl}$ & 14 & $\mathrm{Zn}$ & 44 & $\mathrm{Re}$ & 6 & $\mathrm{Eu}$ & 2 & & \\
\hline $\mathrm{Mg}$ & 40 & $\mathrm{Si}$ & 28 & $\mathrm{Cd}$ & 32 & $\mathrm{Fe}$ & 18 & $\mathrm{Gd}$ & 1 & & \\
\hline $\mathrm{Ca}$ & 12 & $\mathrm{Ge}$ & 12 & $\mathrm{Hg}$ & 4 & $\mathrm{Co}$ & 19 & $\mathrm{Dy}$ & 1 & & \\
\hline
\end{tabular}

Table 4

Coefficient of thermal conductivity of metallic nanowires with a diameter of $\mathbf{1 0} \mathbf{~ n m}$

\begin{tabular}{|c|c|c|c|c|c|c|c|c|c|c|c|}
\hline $\mathrm{M}$ & $\begin{array}{c}\lambda(r), \\
\mathrm{Wt} /(\mathrm{m} \cdot \mathrm{K})\end{array}$ & $\mathrm{M}$ & $\begin{array}{c}\lambda(r), \\
\mathrm{Wt} /(\mathrm{m} \cdot \mathrm{K})\end{array}$ & $\mathrm{M}$ & $\begin{array}{c}\lambda(r), \\
\mathrm{Wt} /(\mathrm{m} \cdot \mathrm{K})\end{array}$ & $\mathrm{M}$ & $\begin{array}{c}\lambda(r), \\
\mathrm{Wt} /(\mathrm{m} \cdot \mathrm{K})\end{array}$ & $\mathrm{M}$ & $\begin{array}{c}\lambda(r), \\
\mathrm{Wt} /(\mathrm{m} \cdot \mathrm{K})\end{array}$ & $\mathrm{M}$ & $\begin{array}{c}\lambda(r), \\
\mathrm{Wt} /(\mathrm{m} \cdot \mathrm{K})\end{array}$ \\
\hline $\mathrm{Li}$ & 29.3 & $\mathrm{Sr}$ & - & $\mathrm{Sn}$ & 57.0 & $\mathrm{Cr}$ & 52.8 & $\mathrm{Ni}$ & 77.3 & $\mathrm{Ho}$ & 10.3 \\
\hline $\mathrm{Na}$ & 123.5 & $\mathrm{Ba}$ & - & $\mathrm{Pb}$ & 29.6 & $\mathrm{Mo}$ & 111.0 & $\mathrm{Ce}$ & 8.0 & $\mathrm{Er}$ & 10.1 \\
\hline $\mathrm{K}$ & 62.7 & $\mathrm{Al}$ & 180.0 & $\mathrm{Cu}$ & 340.5 & $\mathrm{~W}$ & 82.3 & $\mathrm{Pr}$ & 9.2 & $\mathrm{Tm}$ & 11.2 \\
\hline $\mathrm{Rb}$ & 45.1 & $\mathrm{Ga}$ & 31.1 & $\mathrm{Ag}$ & 342.6 & $\mathrm{Mn}$ & 6.7 & $\mathrm{Nd}$ & 11.7 & $\mathrm{Yb}$ & 24.0 \\
\hline $\mathrm{Cs}$ & 26.4 & $\mathrm{In}$ & 79.3 & $\mathrm{Au}$ & 252.0 & $\mathrm{Tc}$ & 37.5 & $\mathrm{Sm}$ & 9.0 & $\mathrm{Lu}$ & 10.2 \\
\hline $\mathrm{Be}$ & 161.1 & $\mathrm{Tl}$ & 39.5 & $\mathrm{Zn}$ & 100.0 & $\mathrm{Re}$ & 34.2 & $\mathrm{Eu}$ & 8.9 & - & - \\
\hline $\mathrm{Mg}$ & 135.2 & $\mathrm{Si}$ & 124.6 & $\mathrm{Cd}$ & 82.3 & $\mathrm{Fe}$ & 61.5 & $\mathrm{Gd}$ & 7.2 & & - \\
\hline $\mathrm{Ca}$ & 65.8 & $\mathrm{Ge}$ & 46.9 & $\mathrm{Hg}$ & 7.5 & $\mathrm{Co}$ & 59.2 & $\mathrm{Dy}$ & 7.2 & & - \\
\hline
\end{tabular}

Table 5

Coefficient of thermal conductivity of metallic nanowires $50 \mathrm{~nm}$ in diameter

\begin{tabular}{|c|c|c|c|c|c|c|c|c|c|c|c|}
\hline $\mathrm{M}$ & $\begin{array}{c}\lambda(r), \\
\mathrm{Wt} /(\mathrm{m} \cdot \mathrm{K})\end{array}$ & $\mathrm{M}$ & $\begin{array}{c}\lambda(r), \\
\mathrm{Wt} /(\mathrm{m} \cdot \mathrm{K})\end{array}$ & $\mathrm{M}$ & $\begin{array}{c}\lambda(r), \\
\mathrm{Wt} /(\mathrm{m} \cdot \mathrm{K})\end{array}$ & $\mathrm{M}$ & $\begin{array}{c}\lambda(r), \\
\mathrm{Wt} /(\mathrm{m} \cdot \mathrm{K})\end{array}$ & $\mathrm{M}$ & $\begin{array}{c}\lambda(r), \\
\mathrm{Wt} /(\mathrm{m} \cdot \mathrm{K})\end{array}$ & $\mathrm{M}$ & $\begin{array}{c}\lambda(r), \\
\mathrm{Wt} /(\mathrm{m} \cdot \mathrm{K})\end{array}$ \\
\hline $\mathrm{Li}$ & 82.3 & $\mathrm{Sr}$ & - & $\mathrm{Sn}$ & 63 & $\mathrm{Cr}$ & 62 & $\mathrm{Ni}$ & 87 & $\mathrm{Ho}$ & 10 \\
\hline $\mathrm{Na}$ & 136.3 & $\mathrm{Ba}$ & - & $\mathrm{Pb}$ & 33 & $\mathrm{Mo}$ & 143 & $\mathrm{Ce}$ & 10 & $\mathrm{Er}$ & 14 \\
\hline $\mathrm{K}$ & 73.6 & $\mathrm{Al}$ & 198 & $\mathrm{Cu}$ & 378 & $\mathrm{~W}$ & 111 & $\mathrm{Pr}$ & 12 & $\mathrm{Tm}$ & 14 \\
\hline $\mathrm{Rb}$ & 53.7 & $\mathrm{Ga}$ & 32 & $\mathrm{Ag}$ & 394 & $\mathrm{Mn}$ & 8 & $\mathrm{Nd}$ & 15 & $\mathrm{Yb}$ & 14 \\
\hline $\mathrm{Cs}$ & 32.5 & $\mathrm{In}$ & 85 & $\mathrm{Au}$ & 291 & $\mathrm{Tc}$ & 46 & $\mathrm{Sm}$ & 12 & $\mathrm{Lu}$ & 31 \\
\hline $\mathrm{Be}$ & 176 & $\mathrm{Tl}$ & 45 & $\mathrm{Zn}$ & 108 & $\mathrm{Re}$ & 44 & $\mathrm{Eu}$ & 12 & & \\
\hline $\mathrm{Mg}$ & 155 & $\mathrm{Si}$ & 152 & $\mathrm{Cd}$ & 90 & $\mathrm{Fe}$ & 71 & $\mathrm{Gd}$ & 10 & & \\
\hline $\mathrm{Ca}$ & 86 & $\mathrm{Ge}$ & 56 & $\mathrm{Hg}$ & 8 & $\mathrm{Co}$ & 67 & $\mathrm{Dy}$ & 10 & & \\
\hline
\end{tabular}

It can be seen from the tables that the coefficients of thermal conductivity of metals with a size of $1 \mathrm{~nm}$ decrease by a factor of 2 in comparison with bulk samples, and at dimensions of $50 \mathrm{~nm}$ they differ little from the latter. This is significantly different from the dimensional dependence of the melting point. Here there is a change of 2-3 orders of magnitude.

\section{Wiedemann-Franz-Lorenz Law}

The mechanism of heat transfer by heat conduction is based on the concept of energy transfer by gas particles [14-16]. In metals, it is a free electron gas, in the insulators - a phonon gas. Kinetic theory considers the motion of electrons in metals in electric and magnetic fields created by the atoms of matter, and also under the condition of imposing an external thermal field, i.e. in the presence of a temperature gradient. The kinetic approach is based on the Boltzmann equation, taking into account the quantum statistics of the electron gas and various scattering mechanisms: phonons, structure defects, etc. 
Within the framework of the kinetic approach for the classical electron gas, a relation was obtained between the thermal conductivity coefficient $\lambda$ and the electrical conductivity of the metal $\sigma$ :

$$
\lambda=\frac{\pi^{2}}{3} \cdot\left(\frac{k}{e}\right)^{2} \cdot T \sigma
$$

Here $k$ is the Boltzmann constant; $e$ is the electron charge; $T$ is the temperature. The relation (5) is called the Wiedemann-Franz law. In a more general form, this law is written in the form:

$$
\lambda=L \sigma T
$$

and is called the Wiedemann-Franz-Lorentz law.

The universality of this notation is that all the unaccounted features of the behavior of an electron in a metal in deriving the relation (5) can be expressed by different values of the Lorentz number $L$, without changing the form of the relation (6). It is easy to see that, knowing the electrical conductivity of a metal and its temperature, it is also possible to calculate its thermal conductivity, since in the classical case (6) the Lorentz number is constant. Experimental studies have made it possible to establish the validity of the Wiedemann-Franz-Lorentz law in the form (6) for all metals and for many metals in the form (5) [14-16]. In this case, significant deviations from the expression (5) observed in some metals over the entire temperature range were revealed, and in others only at certain temperatures. This is due to both the scattering processes and the band structure of the metal.

In the case of elastic scattering of electrons and a parabolic zone, the Lorentz number can be represented by the following expressions:

- for a strongly degenerate electron gas:

$$
L=L_{0}=\frac{\pi^{2}}{3} \cdot\left(\frac{k}{e}\right)^{2}
$$

those, corresponds to (6);

- for a nondegenerate electron gas:

$$
L=\left(r+\frac{5}{2}\right) \cdot\left(\frac{k}{e}\right)^{2}
$$

where $r$ is the exponent in the dependence of the relaxation time on energy, which is -0.5 when the electron is scattered by acoustic and optical lattice vibrations and 1.5 when scattered by impurity ions.

Dependencies (7) and (8) are applicable for most metals and semiconductors. Table 6 shows the values of electrical conductivity of pure metals, and in Tables 7-9 for metal nanowires with diameters of 1, 10 and $50 \mathrm{~nm}$, calculated by the formula similar to (4), where the coefficient of thermal conductivity is replaced by electrical conductivity.

As in the case of thermal conductivity, the electrical conductivity decreases significantly when the diameter of the nanowires decreases. Table 10 lists Lorentz numbers for a massive sample of metal and nanowires.

Table 10 shows that the Lorentz numbers for a massive sample and nanowires coincide within the error of the experiment. The main contribution to the measurement error is made by the error in determining the coefficient of thermal conductivity, which even for massive samples reaches $10 \%$.

Table 6

Electrical conductivity of pure metals (M) [13]

\begin{tabular}{|c|c|c|c|c|c|c|c|c|c|c|c|}
\hline $\mathrm{M}$ & $\begin{array}{c}\sigma_{0}, 10^{8}, \\
\mathrm{Ohm}^{-1} \cdot \mathrm{m}^{-1}\end{array}$ & $\mathrm{M}$ & $\begin{array}{c}\sigma_{0}, 10^{8}, \\
\mathrm{Ohm}^{-1} \cdot \mathrm{m}^{-1}\end{array}$ & $\mathrm{M}$ & $\begin{array}{c}\sigma_{0}, 10^{8}, \\
\mathrm{Ohm}^{-1} \cdot \mathrm{m}^{-1}\end{array}$ & $\mathrm{M}$ & $\begin{array}{c}\sigma_{0}, 10^{8}, \\
\mathrm{Ohm}^{-1} \cdot \mathrm{m}^{-1}\end{array}$ & $\mathrm{M}$ & $\begin{array}{c}\sigma_{0}, 10^{8}, \\
\mathrm{Ohm}^{-1} \cdot \mathrm{m}^{-1}\end{array}$ & $\mathrm{M}$ & $\begin{array}{c}\sigma_{0}, 10^{8}, \\
\mathrm{Ohm}^{-1} \cdot \mathrm{m}^{-1}\end{array}$ \\
\hline $\mathrm{Li}$ & 11.8 & $\mathrm{Sr}$ & 5.00 & $\mathrm{Sn}$ & 7.8 & $\mathrm{Cr}$ & 5.3 & $\mathrm{Ni}$ & 14.6 & $\mathrm{Ho}$ & 1.1 \\
\hline $\mathrm{Na}$ & 23.8 & $\mathrm{Ba}$ & 2.00 & $\mathrm{~Pb}$ & 4.9 & $\mathrm{Mo}$ & 19.8 & $\mathrm{Ce}$ & 1.3 & $\mathrm{Er}$ & 0.93 \\
\hline $\mathrm{K}$ & 16.3 & $\mathrm{Al}$ & 37.2 & $\mathrm{Cu}$ & 59.8 & $\mathrm{~W}$ & 18.2 & $\mathrm{Pr}$ & 1.5 & $\mathrm{Tm}$ & 1.3 \\
\hline $\mathrm{Rb}$ & 8.62 & $\mathrm{Ga}$ & 7.3 & $\mathrm{Ag}$ & 68.0 & $\mathrm{Mn}$ & 0.14 & $\mathrm{Nd}$ & 1.6 & $\mathrm{Yb}$ & 3.7 \\
\hline $\mathrm{Cs}$ & 4.76 & $\mathrm{In}$ & 12.2 & $\mathrm{Au}$ & 48.3 & $\mathrm{Tc}$ & - & $\mathrm{Sm}$ & 1.1 & $\mathrm{Lu}$ & 1.3 \\
\hline $\mathrm{Be}$ & 36.0 & $\mathrm{Tl}$ & 5.7 & $\mathrm{Zn}$ & 16.9 & $\mathrm{Re}$ & 5.3 & $\mathrm{Eu}$ & 1.2 & & \\
\hline $\mathrm{Mg}$ & 22.7 & $\mathrm{Si}$ & - & $\mathrm{Cd}$ & 13.5 & $\mathrm{Fe}$ & 10.3 & $\mathrm{Gd}$ & 0.71 & & \\
\hline $\mathrm{Ca}$ & 24.4 & $\mathrm{Ge}$ & - & $\mathrm{Hg}$ & 1.04 & $\mathrm{Co}$ & 16.0 & $\mathrm{Dy}$ & 1.8 & & \\
\hline
\end{tabular}


Electrical conductivity of metal nanowires with a diameter of $1 \mathrm{~nm}$

\begin{tabular}{|c|c|c|c|c|c|c|c|c|c|c|c|}
\hline $\mathrm{M}$ & $\begin{array}{c}\sigma, 10^{8}, \\
\mathrm{Ohm}^{-1} \cdot \mathrm{m}^{-1}\end{array}$ & $\mathrm{M}$ & $\begin{array}{c}\sigma, 10^{8}, \\
\mathrm{Ohm}^{-1} \cdot \mathrm{m}^{-1}\end{array}$ & $\mathrm{M}$ & $\begin{array}{c}\sigma, 10^{8}, \\
\mathrm{Ohm}^{-1} \cdot \mathrm{m}^{-1}\end{array}$ & $\mathrm{M}$ & $\begin{array}{c}\sigma, 10^{8}, \\
\mathrm{Ohm}^{-1} \cdot \mathrm{m}^{-1}\end{array}$ & $\mathrm{M}$ & $\begin{array}{c}\sigma, 10^{8}, \\
\mathrm{Ohm}^{-1} \cdot \mathrm{m}^{-1}\end{array}$ & $\mathrm{M}$ & $\begin{array}{c}\sigma, 10^{8}, \\
\mathrm{Ohm}^{-1} \cdot \mathrm{m}^{-1}\end{array}$ \\
\hline $\mathrm{Li}$ & 4.9 & $\mathrm{Sr}$ & 0.54 & $\mathrm{Sn}$ & 2.6 & $\mathrm{Cr}$ & 1.1 & $\mathrm{Ni}$ & 4.0 & $\mathrm{Ho}$ & 0.1 \\
\hline $\mathrm{Na}$ & 7.7 & $\mathrm{Ba}$ & 0.2 & $\mathrm{~Pb}$ & 1.4 & $\mathrm{Mo}$ & 2.6 & $\mathrm{Ce}$ & 0.2 & $\mathrm{Er}$ & 0.1 \\
\hline $\mathrm{K}$ & 3.5 & $\mathrm{Al}$ & 11.6 & $\mathrm{Cu}$ & 18.1 & $\mathrm{~W}$ & 1.9 & $\mathrm{Pr}$ & 0.2 & $\mathrm{Tm}$ & 0.2 \\
\hline $\mathrm{Rb}$ & 1.7 & $\mathrm{Ga}$ & 3.8 & $\mathrm{Ag}$ & 16.5 & $\mathrm{Mn}$ & 0.04 & $\mathrm{Nd}$ & 0.2 & $\mathrm{Yb}$ & 0.5 \\
\hline $\mathrm{Cs}$ & 0.8 & $\mathrm{In}$ & 4.7 & $\mathrm{Au}$ & 11.2 & $\mathrm{Tc}$ & - & $\mathrm{Sm}$ & 0.2 & $\mathrm{Lu}$ & 0.1 \\
\hline $\mathrm{Be}$ & 12.9 & $\mathrm{Tl}$ & 1.7 & $\mathrm{Zn}$ & 6.8 & $\mathrm{Re}$ & 0.7 & $\mathrm{Eu}$ & 0.1 & & \\
\hline $\mathrm{Mg}$ & 5.5 & $\mathrm{Si}$ & - & $\mathrm{Cd}$ & 4.7 & $\mathrm{Fe}$ & 2.5 & $\mathrm{Gd}$ & 0.1 & & \\
\hline $\mathrm{Ca}$ & 3.1 & $\mathrm{Ge}$ & - & $\mathrm{Hg}$ & 0.6 & $\mathrm{Co}$ & 4.2 & $\mathrm{Dy}$ & 0.2 & & \\
\hline
\end{tabular}

Table 8

Electrical conductivity of metal nanowires with a diameter of $10 \mathrm{~nm}$

\begin{tabular}{|c|c|c|c|c|c|c|c|c|c|c|c|}
\hline $\mathrm{M}$ & $\begin{array}{c}\sigma, 10^{8}, \\
\mathrm{Ohm}^{-1} \cdot \mathrm{m}^{-1}\end{array}$ & $\mathrm{M}$ & $\begin{array}{c}\sigma, 10^{8}, \\
\mathrm{Ohm}^{-1} \cdot \mathrm{m}^{-1}\end{array}$ & $\mathrm{M}$ & $\begin{array}{c}\sigma, 10^{8}, \\
\mathrm{Ohm}^{-1} \cdot \mathrm{m}^{-1}\end{array}$ & $\mathrm{M}$ & $\begin{array}{c}\sigma, 10^{8}, \\
\mathrm{Ohm}^{-1} \cdot \mathrm{m}^{-1}\end{array}$ & $\mathrm{M}$ & $\begin{array}{c}\sigma, 10^{8}, \\
\mathrm{Ohm}^{-1} \cdot \mathrm{m}^{-1}\end{array}$ & $\begin{array}{c}\sigma, 10^{8} \\
\mathrm{Ohm}^{-1} \cdot \mathrm{m}^{-1}\end{array}$ \\
\hline $\mathrm{Li}$ & 10.4 & $\mathrm{Sr}$ & 2.7 & $\mathrm{Sn}$ & 6.5 & $\mathrm{Cr}$ & 3.8 & $\mathrm{Ni}$ & 11.5 & $\mathrm{Ho}$ & 0.6 \\
\hline $\mathrm{Na}$ & 19.7 & $\mathrm{Ba}$ & 1.1 & $\mathrm{~Pb}$ & 3.9 & $\mathrm{Mo}$ & 12.0 & $\mathrm{Ce}$ & 0.8 & $\mathrm{Er}$ & 0.5 \\
\hline $\mathrm{K}$ & 11.9 & $\mathrm{Al}$ & 30.5 & $\mathrm{Cu}$ & 48.6 & $\mathrm{~W}$ & 9.9 & $\mathrm{Pr}$ & 0.9 & $\mathrm{Tm}$ & 0.7 \\
\hline $\mathrm{Rb}$ & 6.1 & $\mathrm{Ga}$ & 6.7 & $\mathrm{Ag}$ & 51.9 & $\mathrm{Mn}$ & 0.11 & $\mathrm{Nd}$ & 1.0 & $\mathrm{Yb}$ & 2.2 \\
\hline $\mathrm{Cs}$ & 3.1 & $\mathrm{In}$ & 11.0 & $\mathrm{Au}$ & 36.3 & $\mathrm{Tc}$ & - & $\mathrm{Sm}$ & 0.7 & $\mathrm{Lu}$ & 0.7 \\
\hline $\mathrm{Be}$ & 30.5 & $\mathrm{Tl}$ & 4.6 & $\mathrm{Zn}$ & 14.7 & $\mathrm{Re}$ & 3.1 & $\mathrm{Eu}$ & 0.7 & & \\
\hline $\mathrm{Mg}$ & 17.3 & $\mathrm{Si}$ & - & $\mathrm{Cd}$ & 11.3 & $\mathrm{Fe}$ & 7.9 & $\mathrm{Gd}$ & 0.4 & & \\
\hline $\mathrm{Ca}$ & 14.4 & $\mathrm{Ge}$ & - & $\mathrm{Hg}$ & 0.9 & $\mathrm{Co}$ & 12.5 & $\mathrm{Dy}$ & 1.0 & & \\
\hline
\end{tabular}

Table 9

Electrical conductivity of metal nanowires with a diameter of $50 \mathrm{~nm}$

\begin{tabular}{|c|c|c|c|c|c|c|c|c|c|c|c|}
\hline $\mathrm{M}$ & $\begin{array}{c}\sigma, 10^{8}, \\
\mathrm{Ohm}^{-1} \cdot \mathrm{m}^{-1}\end{array}$ & $\mathrm{M}$ & $\begin{array}{c}\sigma, 10^{8}, \\
\mathrm{Ohm}^{-1} \cdot \mathrm{m}^{-1}\end{array}$ & $\mathrm{M}$ & $\begin{array}{c}\sigma, 10^{8}, \\
\mathrm{Ohm}^{-1} \cdot \mathrm{m}^{-1}\end{array}$ & $\mathrm{M}$ & $\begin{array}{c}\sigma, 10^{8}, \\
\mathrm{Ohm}^{-1} \cdot \mathrm{m}^{-1}\end{array}$ & $\mathrm{M}$ & $\begin{array}{c}\sigma, 10^{8}, \\
\mathrm{Ohm}^{-1} \cdot \mathrm{m}^{-1}\end{array}$ & $\begin{array}{c}\mathrm{M}, 10^{8}, \\
\mathrm{Ohm}^{-1} \cdot \mathrm{m}^{-1}\end{array}$ \\
\hline $\mathrm{Li}$ & 11.5 & $\mathrm{Sr}$ & 4.3 & $\mathrm{Sn}$ & 7.5 & $\mathrm{Cr}$ & 4.9 & $\mathrm{Ni}$ & 13.0 & $\mathrm{Ho}$ & 1.0 \\
\hline $\mathrm{Na}$ & 22.8 & $\mathrm{Ba}$ & 1.7 & $\mathrm{~Pb}$ & 4.7 & $\mathrm{Mo}$ & 17.5 & $\mathrm{Ce}$ & 1.2 & $\mathrm{Er}$ & 0.8 \\
\hline $\mathrm{K}$ & 15.2 & $\mathrm{Al}$ & 35.6 & $\mathrm{Cu}$ & 57.2 & $\mathrm{~W}$ & 15.6 & $\mathrm{Pr}$ & 1.3 & $\mathrm{Tm}$ & 1.1 \\
\hline $\mathrm{Rb}$ & 8.0 & $\mathrm{Ga}$ & 7.2 & $\mathrm{Ag}$ & 64.0 & $\mathrm{Mn}$ & 0.13 & $\mathrm{Nd}$ & 1.4 & $\mathrm{Yb}$ & 3.3 \\
\hline $\mathrm{Cs}$ & 4.3 & $\mathrm{In}$ & 11.8 & $\mathrm{Au}$ & 45.3 & $\mathrm{Tc}$ & - & $\mathrm{Sm}$ & 1.0 & $\mathrm{Lu}$ & 1.1 \\
\hline $\mathrm{Be}$ & 34.8 & $\mathrm{Tl}$ & 5.4 & $\mathrm{Zn}$ & 16.4 & $\mathrm{Re}$ & 4.6 & $\mathrm{Eu}$ & 1.0 & & \\
\hline $\mathrm{Mg}$ & 21.4 & $\mathrm{Si}$ & - & $\mathrm{Cd}$ & 13.0 & $\mathrm{Fe}$ & 9.7 & $\mathrm{Gd}$ & 0.6 & & \\
\hline $\mathrm{Ca}$ & 21.4 & $\mathrm{Ge}$ & - & $\mathrm{Hg}$ & 1.0 & $\mathrm{Co}$ & 15.2 & $\mathrm{Dy}$ & 1.6 & & \\
\hline
\end{tabular}

Lorentz numbers of some metals

( $L_{0}$ - bulk sample [13], $L_{1}, L_{10}$ - for nanowires with a diameter of 1 and $10 \mathrm{~nm}$, respectively)

\begin{tabular}{|c|c|c|c|c|c|c|c|}
\hline $\mathrm{M}$ & $\begin{array}{c}L_{0}, 10^{-8}, \\
\mathrm{Wt} \cdot \mathrm{Ohm} / \mathrm{K}^{2}\end{array}$ & $\begin{array}{c}L_{0}, 10^{-8}, \\
\mathrm{Wt} \cdot \mathrm{Ohm} / \mathrm{K}^{2}\end{array}$ & $\begin{array}{c}L_{0}, 10^{-8}, \\
\mathrm{Wt} \cdot \mathrm{Ohm} / \mathrm{K}^{2}\end{array}$ & $\mathrm{M}$ & $\begin{array}{c}L_{0}, 10^{-8}, \\
\mathrm{Wt} \cdot \mathrm{Ohm} / \mathrm{K}^{2}\end{array}$ & $\begin{array}{c}L_{0}, 10^{-8}, \\
\mathrm{Wt} \cdot \mathrm{Ohm} / \mathrm{K}^{2}\end{array}$ & $\begin{array}{c}L_{0}, 10^{-8}, \\
\mathrm{Wt} \cdot \mathrm{Ohm} / \mathrm{K}^{2}\end{array}$ \\
\hline $\mathrm{Li}$ & 2.22 & 2.40 & 2.40 & $\mathrm{Fe}$ & 2.61 & 2.40 & 2.40 \\
\hline $\mathrm{Na}$ & 2.12 & 2.00 & 2.00 & $\mathrm{Zn}$ & 2.28 & 2.20 & 2.20 \\
\hline $\mathrm{K}$ & 2.23 & 2.00 & 2.00 & $\mathrm{Cd}$ & 2.49 & 2.16 & 2.16 \\
\hline $\mathrm{Rb}$ & 2.42 & 2.20 & 2.20 & $\mathrm{Al}$ & 2.14 & 2.00 & 2.00 \\
\hline $\mathrm{Cu}$ & 2.20 & 2.21 & 2.21 & $\mathrm{In}$ & 2.58 & 2.41 & 2.41 \\
\hline $\mathrm{Ag}$ & 2.31 & 2.06 & 2.10 & $\mathrm{Tl}$ & 2.75 & 2.75 & 2.75 \\
\hline $\mathrm{Au}$ & 2.32 & 2.14 & 2.14 & $\mathrm{Sn}$ & 2.48 & 2.82 & 2.82 \\
\hline $\mathrm{Be}$ & 2.36 & 2.00 & 2.00 & $\mathrm{~Pb}$ & 2.64 & 2.38 & 2.38 \\
\hline
\end{tabular}


The result obtained indicates that heat transfer in metallic nanostructures is accomplished by electrons as in bulk samples.

\section{The Fuchs-Sondheimer Model}

The classical theory of the size effect in the electrical conductivity of thin films was formed in the middle of the twentieth century and was called the Fuchs-Sondheimer model [17]. The model is based on the solution of the Boltzmann kinetic equation with allowance for the scattering on the walls of the film. For the specific resistance $\rho$ of a thin film (or nanowire) with a thickness $d$ and mean free path $\ell \infty$, the following expressions are obtained:

$$
\begin{gathered}
\rho=\rho_{0}\left(1+\frac{3}{8} \frac{\ell_{\infty}}{d}\right), d>>\ell_{\infty} ; \\
\rho=\rho_{0}\left(\frac{4}{3} \frac{\ell_{\infty}}{d}\left(\ln \frac{\ell_{\infty}}{d}\right)^{-1}\right), d<<\ell_{\infty} .
\end{gathered}
$$

The relations obtained can be interpreted in terms of a decrease in the mean free path of electrons during scattering on the walls of the film with a decrease in its thickness.

If the film thickness is commensurable with the electron de Broglie wavelength, a quantum size effect can be realized. Its essence lies in the fact that the transverse motion of the electrons becomes quantized: the projection of the quasimomentum of an electron on a small-size direction can take only a discrete set of values. In pure metals, the de Broglie wavelength of electrons is of the order of $0.1 \mathrm{~nm}$, which is an order of magnitude larger than the smallest film size considered in our case. Thus, when considering dimensional effects in metallic nanostructures with a size of $1-50 \mathrm{~nm}$, we remain within the framework of a classical or semiclassical electron gas.

We estimate the mean free path of electrons in metals from Eq [17]:

$$
\ell=\left(\frac{3}{8 \pi}\right)^{1 / 3} \cdot \frac{h}{e^{2} n_{e}^{2 / 3}} \sigma_{0} .
$$

Here $e$ is the electron charge; $h$ is the Planck constant; $n_{e}$ is the electron concentration: $\sigma_{0}$ is the electrical conductivity of the bulk sample from Table 5.

The corresponding estimates gave the following result: for $\mathrm{Al} \ell=14.7 \mathrm{~nm}$; for $\mathrm{Au} \ell=36.5 \mathrm{~nm}$; for $\mathrm{Cu}$ $\ell=38.9 \mathrm{~nm}$; for $\mathrm{Ag} \ell=56.3 \mathrm{~nm}$. We now make an estimate of the conductivity of a gold film of thickness $d=1 \mathrm{~nm}$ by formula (10), taking into account that $\sigma=1 / \mathrm{\rho}$. We get that $\sigma=3.8610^{-8} \Omega^{-1} \mathrm{~m}^{-1}$ against $\sigma=11.2 \cdot 10^{-8} \Omega^{-1} \mathrm{~m}^{-1}$ from Table 6 .

As we can see, the calculated conductivity value by formula (11) differs from our value by about 3 times in the smaller direction. This is due to the fact that in formula (11) we take the mean free path in a massive sample. If we take into account the dimensional dependence of the mean free path of an electron and use (3) to calculate it, then after substituting this into formula (10), we obtain this value for a $1 \mathrm{~nm}$ gold film $\sigma=9.810^{-8} \Omega^{-1} \mathrm{~m}^{-1}$, which is already slightly different from the value given in Table 6 .

From the above arguments it follows that for the metal nanostructures the Fuchs-Sondheimer model works well when taking into account the dimensional dependence of the mean free path of an electron in accordance with relation (5).

Taking into account the results given in Table 9, we can conclude that the Wiedemann-Franz-Lorentz law in the form (6) is satisfied for all metal nanostructures up to $1 \mathrm{~nm}$ and for many metallic nanostructures in the form (5). Thus, all the above results for the electrical conductivity of metallic nanostructures can also be used for thermal conductivity.

\section{The Landauer-Datt-Lundstrom model}

The analysis of the modern theory of the transfer of electrons and heat of Landauer-Datta-Lundstrom (LDL) is carried out in [18], which is applicable for 1D, 2D and 3D nanostructure and macroscale resistors in ballistic, quasi-ballistic and diffusion modes of linear response in the presence of voltage and temperature drop at the ends of the device.

It is shown that the Landauer-Datt-Lundstrom principle, used to describe electron transfer, can be generalized for phonons. In both cases, the Landauer approach, the generalized and extended Data and Lundstrom, gives a correct qualitative description of the transport processes for resistors of any size and scale in the ballistic, quasi-ballistic and diffusion modes of the linear response in the presence of a voltage 
drop and temperature at the ends of the device. It is shown [18] that lattice thermal conductivity can be written in a form very close to electrical conductivity, but there are two important differences. The first difference between electrons and phonons is the difference in the width of their dispersion bands. For electrons, the dispersion is $B W>>k T$ at room temperature, so only low-energy states are occupied. For phonons $B W \approx k T$, therefore, all acoustic modes are occupied at room temperature throughout the Brillouin zone. As a result, the simple Debye approximation in the dispersion of acoustic phonons does not work, much like the simple approximation of the effective mass with respect to the electron dispersion. The second difference between electrons and phonons is that for electrons the mode populations are controlled by the conduction window function, which depends on the position of the Fermi level and temperature. For phonons, the conduction window function depends only on temperature. As a result, when the position of the Fermi level changes, the electrical conductivity changes by many orders of magnitude, and the lattice conductivity changes by only several orders of magnitude.

\section{Thermal conductivity of nanowires taking into account the size effect}

In all the guidelines for calculating the thermal fields of thin coatings of space and aviation equipment, we start with the classical heat conduction equations, where the thermal conductivity coefficient is assumed to be a constant value (see, for example [19]). As we showed above, when the thickness of a metal film is less than $50-100 \mathrm{~nm}$, its physical properties are affected by dimensional effects. Let us consider the problem of the thermal field of an unbounded plate of thickness $\delta$. For simplicity and comparison, we confine ourselves to the stationary case. Then the heat equation will have the form:

$$
\frac{d}{d x}\left(\lambda \frac{d T}{d x}\right)=0 .
$$

In the classical case, $\lambda=$ const, and in our case $\lambda=\lambda_{0}(1-\alpha / \alpha+x)$. Unlike (3), here the size factor is denoted by $\alpha$, so as not to be confused with the sign of differentiation.

Taking into account the size effect, equation (12) reduces to the form:

$$
\frac{x}{x+\alpha} \frac{d T}{d x}=\frac{C_{1}}{\lambda_{0}} .
$$

Here $C_{1}$ is the integration constant. The solution of equation (13) has the form:

$$
T(x)=\frac{C_{1}}{\lambda_{0}}(x+\alpha \ln x)+C_{2} .
$$

If $\lambda=$ const in (12), then we have the classical solution of the problem for an unbounded plate:

$$
T(x)=C_{1} x+C_{2} .
$$

In contrast to the classical problem, a logarithmic term appears in equation (14). This leads to divergence at the origin. Therefore, the boundary conditions must be specified not for $x=0$, but for $x=\lambda_{\infty}-$ the mean free path of the electrons. Only in this case the classical heat equation is meaningful.

It is also essential that, according to (14), the heat field of the nanoplate depends both on the material of the plate through the thermal conductivity coefficient of the bulk sample $\lambda_{0}$ and on the size factor $\alpha$. In the classical case, there is no such dependence.

For equation (13), the first boundary value problem will look like this:

$$
\begin{gathered}
\left.T(x)\right|_{x=\lambda_{\infty}}=\frac{C_{1}}{\lambda_{0}}\left(\lambda_{\infty}+\alpha \ln \lambda_{\infty}\right)+C_{2}=T_{1} ; \\
\left.T(x)\right|_{x=h}=\frac{C_{1}}{\lambda_{0}}(h+\alpha \ln h)+C_{2}=T_{2} .
\end{gathered}
$$

From the system of equations (16) it follows that:

$$
\begin{gathered}
T_{1}=\frac{C_{1}}{\lambda_{0}}\left(\lambda_{\infty}+\alpha \ln \lambda_{\infty}\right)+C_{2} ; \\
T_{2}=\frac{C_{1}}{\lambda_{0}}(h+\alpha \ln h)+C_{2} .
\end{gathered}
$$


Subtracting the second from the first equation, we obtain:

$$
\begin{gathered}
T_{1}-T_{2}=\frac{C_{1}}{\lambda_{0}}\left[\left(\lambda_{\infty}+\alpha \ln \lambda_{\infty}\right)-(h+\alpha \ln h)\right]=C_{1} \gamma / \lambda_{0} ; \\
C_{1}=\frac{\left(T_{1}-T_{2}\right) \cdot \lambda_{0}}{\gamma} ; \\
C_{2}=T_{1}-\frac{\left(T_{1}-T_{2}\right) \cdot\left(\lambda_{\infty}+\alpha \ln \lambda_{\infty}\right)}{\gamma} .
\end{gathered}
$$

The general solution of the problem will have the form $(\alpha=d)$ :

$$
T(x)=\frac{\left(T_{1}-T_{2}\right) \cdot \lambda_{0}}{\gamma} \cdot(x+d \cdot \ln x)+T_{1}-\frac{\left(T_{1}-T_{2}\right) \cdot\left(\lambda_{\infty}+d \cdot \ln \lambda_{\infty}\right)}{\gamma} .
$$

The general solution of the classical problem has the form:

$$
T(x)=\frac{T_{2}-T_{1}}{h} x+T_{1} .
$$

Comparison of (18) and (19) shows that the thermal field of a plate of nanometer thickness differs significantly from a massive sample.

\section{Conclusion}

The recent creation of complex devices based on nanoobjects (nanotransistors, nanoelectromechanical devices, nanothermoelectric devices, etc.) requires a serious analysis of thermal processes in nanoobjects and nanosystems. In addition to the rapid development of nanoelectronics, no less unexpected applications of nanotechnology have appeared, in particular in power engineering, transport, rocket and space technology, applied chemistry, etc.

In this paper it is shown that taking into account the size effects in the thermal conductivity of metal nanostructures leads to significant differences in comparison with bulk samples.

The work was carried out under the program of the Ministry of Education and Science of the Republic of Kazakhstan Grants No. $0118 R$ K000063 and No. F.0780.

\section{References}

1 Дмитриев А.С. Тепловые процессы в наноструктурах / А.С. Дмитриев. - М.: Изд. дом МЭИ, 2012. - 302 с.

2 Fisher T.S. Thermal Energy at the Nanoscale / T.S. Fisher. - Singapore: World Scientific, 2013. - 171 p.

3 Cahill D.G. Nanoscale Thermal Transport / D.G. Cahill, W.K. Ford, K.E. Goodson, G.D. Mahan, A. Madjumar, H.J. Maris, R. Merlin // J. Appl. Phys. — 2003. - Vol. 93, No. 2. - P. 793-802.

4 Cahill D.G. Nanoscale Thermal Transport II / D.G. Cahill, P.V. Braun, G. Chen, D.R. Clarke, S. Fan, K.E. Goodson, P.Keblinski et al. // Appl. Phys. Rev. — 2014. — Vol. 1, No. 1. — P. 011305.

5 Дмитриев А.С. Введение в нанотеплофизику / А.С. Дмитриев. - М.: БИНОМ, 2015. - 792 с.

6 Хвесюк В.И. Теплопроводность наноструктур / В.И. Хвесюк, А.С. Скрябин // Теплофизика высоких температур. 2017. - Т. 55, № 3. - С. 447-471.

7 Peierls R.E. Zur kinetischen Theorie der Warmelitung in Kristallen / R.E. Peierls // Ann. Phys. — 1929. — Vol. 395. — P. 1055-1066.

8 Klemens P. Thermal Conductivity and Lattice Vibrational Modes / Klemens P. // Solid State Phys. — 1958. — Vol. 7. — P. 1-23.

9 Непийко С.А. Физические свойства малых металлических частиц / С.А. Непийко. - Киев: Наук. думка, 1985. $243 \mathrm{c}$.

10 Макаров Г.Н. Экспериментальные методы определения температуры и теплоты плавления кластеров и наночастиц / Г.Н. Макаров // УФН. — 2010. — Т. 180, № 2. — С. 185-207.

11 Юров В.М. Поверхностное натяжение твердых тел / В.М. Юров // Вестн. Караганд. ун-та. Сер. Физика. — 2007. — № 1(45). - C. 23-29.

12 Yurov V.M. Superfecial tension of pure metals / V.M. Yurov // Eurasian Physical Technical Journal. — 2011. — Vol. 8, No. 1(15). - P. 10-14.

13 Таблицы физических величин. Справочник / под ред. акад. И.К. Кикоина. - М.: Атомиздат, 1976. - 1008 с.

14 Мейлихов Е.3. Электроны и фононы в общей физике твердого тела / Е.3. Мейлихов. - М.: МФТИ, 2005. — 72 с.

15 Brewster H.D. Solid State Physics / H.D. Brewster. — Oxford Book Company, 2009. — 286 p.

16 Quinn J.J. Solid state physics: principles and modern applications / J.J. Quinn, K.-S. Yi. — Berlin: Springer, 2009. — 536 p.

17 Chopra K.L. Thin Film Phenomena / K.L. Chopra. — N.-Y.: McGrow-Hill, 1969. — 844 p. 
18 Кругляк Ю.А. Электрический ток, термоток и тепловой поток в нано-и микроэлектронике: модель переноса / Ю.А. Кругляк // Термоэлектричество. — 2014. — № 6. - С. 7-28.

19 Шкарбан И.И. Теплофизика элементов космической техники и процессов формирования наноструктур / И.И. Шкарбан. — Калуга; М.: Эйдос, 2011. - 262 с.

\author{
В.М. Юров, Г.А. Ранова, С.А. Гученко, В.Ч. Лауринас \\ Металл наножіптердің және наноқабыршақтардың \\ жылуөткізгіштігінің мәселесіне
}

\begin{abstract}
Соңғы жылдары наноқұрылымдардың термофизикалық қасиеттерін зерттеуге назар аударылуда, бұл құрылымдардың ғылымның, технологияның, медицина және тағы басқа барлық салаларда қолданылуымен ашылатын мүмкіндіктерге байланысты. Зерттеулер макроскопиялық денелерде және наноқұрылымдарда жылу беру сипатында айтарлықтай айырмашылықтар бар екенін көрсетті. Бұл мәселенің тағы бір ерекшелігі - арнайы теориялық және тәжірибелік зерттеу әдістерін әзірлеуді қажет ететін көптеген нысандар. Осыған байланысты қатты күйдегі наноқұрылымдарда жылу беру мәселесі белсенді зерттеу аймағы болып табылады. Бірқатар жұмыстарда, біз көрсеткендей, алынған теңдеулер (1)-(3) әмбебап сипатқа ие және наноқұрылымдардың, соның ішінде термофизикалық көптеген қасиеттерінің өлшемді тәуелділігі үшін жарамды. Мақалада металл наноқұрылымдардың жылуөткізгіштік және электрөткізгіштігі және жұқа қабыршақтардың жылуөткізгіштігінің типтік мәселелері қарастырылған. Металл наноқұрылымдар үшін Фукс-Зондхеймер моделі электронның орташа еркін жолының өлшемді тәуелділігін ескере отырып, жақсы жұмыс істейтіні туралы мақалада келтірілген нәтижелерден туындайды. Ғарыштық және авиациялық жабдықтардың жұқа жабындарының жылулық өрістерін есептеуге арналған барлық нұсқаулықтарда жылуөткізгіштік коэффициенті тұрақты мән деп саналатын классикалық жылу өткізгіштік теңдеулерінен басталады. Осы мақалада біз металл қабатының қалыңдығы 50-100 нм-нен аз болғанда, оның физикалық қасиеттері мөлшерлік әсерлерден әсер еткенін көрсеттік. Шағын қалыңдығы шексіз плитаның жылу өрісінің мәселесі зерттелді. Нанотілімшенің жылу өрісі массивтік үлгідегі жылуөткізгіштік коэффициенті және өлшем факторы бойынша тілімшенің материалына да байланысты. Классикалық жағдайда мұндай тәуелділік жоқ.
\end{abstract}

Кілт сөздер: жылуөткізгіштік, электрөткізгіштік, наножіп, наноқабыршақ, әсер мөлшері, жылуфизика.

\author{
В.М. Юров, Г.А. Ранова, С.А. Гученко, В.Ч. Лауринас
}

\title{
К вопросу о теплопроводности металлических нанонитей и нанопленок
}

\begin{abstract}
В последние годы растет внимание к исследованиям теплофизических свойств наноструктур, что связано с возможностями, которые открываются при использовании этих структур практически во всех областях науки, техники, медицины и т.п. Исследования показывают наличие существенных отличий в характере переноса тепла внутри макроскопических тел и в наноструктурах. Другая особенность этой проблемы - большое разнообразие объектов, требующих развития специальных теоретических и экспериментальных методов исследования. В связи с этим вопросы переноса тепла в твердотельных наноструктурах являются в настоящее время областью активных исследований. Как показано нами в ряде работ, полученные уравнения (1)-(3) имеют универсальный характер и справедливы для размерной зависимости многих свойств наноструктур, включая и теплофизические. В настоящей работе изложенный подход использован при рассмотрении теплопроводности и электропроводности металлических наноструктур и некоторых типичных задач теплопроводности тонких пленок. Из приведенных в работе результатов следует, что для металлических наноструктур модель Фукса-Зондхеймера работает неплохо при учете размерной зависимости длины свободного пробега электрона. Во всех руководствах по расчету тепловых полей тонких покрытий космической и авиационной техники исходят из классических уравнений теплопроводности, где коэффициент теплопроводности считается постоянной величиной. Авторами показано, что при толщине металлической пленки менее 50-100 нм в ее физических свойствах начинают сказываться размерные эффекты. Рассмотрена задача о тепловом поле неограниченной пластины малой толщины. Показано, что тепловое поле нанопластины зависит как от материала пластины через коэффициент теплопроводности массивного образца, так и от размерного фактора. В классическом случае такой зависимости нет.
\end{abstract}

Ключевые слова: теплопроводность, электропроводность, нанонить, нанопленка, размерный эффект, теплофизика. 


\section{References}

1 Dmitriev, A.S. (2012). Teplovye protsessy v nanostrukturakh [Thermal processes in nanostructures]. Moscow: Izdatelskii dom «MEI» [in Russian].

2 Fisher, T.S. (2013). Thermal Energy at the Nanoscale, Singapore: World Scientific.

3 Cahill, D.G., Ford, W.K., Goodson, K.E., Mahan, G.D., Madjumar A., \& Maris H.J., et al. (2003). Nanoscale Thermal Transport, J. Appl. Phys., 93(2), 793-802.

4 Cahill, D.G., Braun, P.V., Chen, G., Clarke, D.R., Fan, S., \& Goodson, K.E., et al. (2014). Nanoscale Thermal Transport II, Appl. Phys. Rev., 1(1), 011305.

5 Dmitriev, A.S. (2015). Vvedenie v nanoteplofiziku [Introduction to thermal physics]. Moscow: BINOM [in Russian].

6 Hvesiuk, V.I., \& Skriabin, A.S. (2017). Teploprovodnost nanostruktur [Thermal conductivity of nanostructures]. Teplofizika vysokikh temperatur - Thermal physics of high temperatures, 55(3), 447-471 [in Russian].

7 Peierls, R.E. (1929). Zur kinetischen Theorie der Warmelitung in Kristallen, Ann. Phys., 395, 1055-1066.

8 Klemens, P. (1958). Thermal Conductivity and Lattice Vibrational Modes, Solid State Phys., 7, 1-23.

9 Nepiiko, S.A. (1985). Fizicheskie svoistva malykh metallicheskikh chastits [Physical properties of small metal particles]. Kiev: Naukova Dumka [in Russian].

10 Makarov, G.N. (2010). Eksperimentalnye metody opredeleniia temperatury i teploty plavleniia klasterov i nanochastits [Experimental methods for determining the temperature and heat of fusion of clusters and nanoparticles]. Uspekhi fizicheskikh nauk Russian physics journal, 180(2), 185-207. [in Russian].

11 Yurov, V.M. (2007). Poverkhnostnoe natiazhenie tverdykh tel [Surface tension of solids]. Vestnik Karahandinskoho universiteta. Ser. Fizika - Bulletin of Karaganda University. Ser. Physics, 1(45), $23-29$ [in Russian].

12 Yurov, V.M. (2011). Superfecial tension of pure metals, Eurasian Physical Technical Journal, 8, 1(15), 10-14.

13 Kikoin, I.K. (Eds.). (1976). Tablitsy fizicheskikh velichin. Spravochnik [Tables of physical quantities. Directory]. Moscow: Atomizdat [in Russian].

14 Meilihov, E.Z. (2005). Elektrony i fonony $v$ obshchei fizike tverdoho tela [Electrons and phonons in general solid state physics]. Moscow: MFTI [in Russian].

15 Brewster, H.D. (2009). Solid State Physics, Oxford Book Company.

16 Quinn, J.J., \& Yi, K.-S. (2009). Solid State Physics: Principles and Modern Applications. Berlin: Springer.

17 Chopra, K.L. (1969). Thin Film Phenomena. New York: McGrow-Hill.

18 Krugliak, Yu.A. (2014). Elektricheskii tok, termotok i teplovoi potok v nano- i mikroelektronike: model perenosa [Electric current, thermocurrent and heat flow in nano- and microelectronics: transport model]. Termoelektrichestvo - Thermoelectricity, 6, 7-28 [in Russian].

19 Shkarban, I.I. (2011). Teplofizika elementov kosmicheskoi tekhniki i protsessov formirovaniia nanostruktur [Thermal physics of elements of space technology and processes of formation of nanostructures]. Kaluga; Moscow: Eidos [in Russian]. 